\title{
THE RELATIONSHIP BETWEEN ECONOMIC ACTIVITIES AND RAIL FREIGHT TRANSPORT
}

\author{
DOI: 10.17261/Pressacademia.2018.962 \\ JMML- V.5-ISS.3-2018(3)-p.182-193
}

\author{
Abdullah Acik', Sadik Ozlen Baser ${ }^{2}$ \\ ${ }^{1}$ Dokuz Eylül University, Denizcilik Fakültesi, Izmir, Turkey. \\ abdullah.acik@deu.edu.tr, ORCID: 0000-0003-4542-9831 \\ ${ }^{2}$ Dokuz Eylül University, Denizcilik Fakültesi, Izmir, Turkey. \\ ozlen.baser@deu.edu.tr, ORCID: 0000-0001-6632-2617
}

Date Received: June 6, 2018

Date Accepted: September 4, 2018

To cite this document

Acik, A., Baser, S. O. (2018). The relationship between economic activities and rail freight transport. Journal of Management, Marketing and Logistics (JMML), V.5(3), p.182-193.

Permemant link to this document: http://doi.org/10.17261/Pressacademia.2018.962

Copyright: Published by PressAcademia and limited licenced re-use rights only.

\section{ABSTRACT}

Purpose- The aim of this study is to determine the relationship between the amount of cargo carried by the railway and economic activities of Turkey, and to contribute to Turkey's determination of the required investment amount by detecting the amount of increase in potential demand of railway transport in our country's progress in achieving the objectives of the 2023 vision. In addition, the emphasis on railways in the transport process will make a significant contribution to the green supply chain objectives by reducing losses to the environment. Methodology- In this study, methodology consists of three methods; firstly, the amount of cargo transported by railways and Turkey's trade volume were analyzed by econometric techniques covering the years 1977-2016, and the coefficients were used to forecast cargo transportation by railways in 2023; secondly, the European Union countries that have similar nature with Turkey were tried to be determined by hierarchical clustering analysis; and thirdly, a data envelopment analysis was implemented to these identified countries. Because, the efficient usage of current infrastructure is also important for planning future investment needs.

Findings- As a result of the econometric analysis, a significant positive relationship was found between the variables. A $1 \%$ increase in trade volume leads to an increase of about $0.35 \%$ in freight loads on rail transport, consequently the increase in the transported cargo was calculated as $85 \%$. According to cluster analysis, Turkey was placed in a group which included United Kingdom, France and Italy, and was the least efficient country in the group considering the results of the data envelopment analysis.

Conclusion- As a result of these analyzes, it was determined that in order to effectively serve the 1.17 trillion-dollar trade volume targeted by our country in 2023, it needed short-term efficiency-enhancing investments and long-term serious infrastructure investments.

Keywords: Rail freight transport, trade volume, efficiency, investment.

JEL Classification: C10, L92, L98

\section{EKONOMIK AKTIVITELER VE DEMIRYOLU TAŞIMACILIĞININ ILIŞKISi}

\section{ÖZET}

Amaç- Bu çalışmanın amacı, Türkiye'nin ekonomik aktiviteleriyle demiryolunda taşınan yük miktarı arasındaki ilişkiyi belirleyip, ülkemizin 2023 vizyonundaki hedeflerine ulaşma sürecindeki olası talep artış miktarını tespit ederek gerekli yatırım miktarlarının belirlenmesine katkıda bulunmaktır. Ayrıca taşıma sürecinde demiryollarına ağılık verilmesi çevreye olan zararları azaltarak yeşil tedarik zinciri hedeflerine de önemli katkıda bulunacaktır.

Metodoloji- Bu çalışmada 3 yöntem kullanılmıştı; ilk olarak, 1977-2016 yılları arasındaki Türkiye'nin ticaret hacmi ve demiryollarında taşınan yük miktarı ekonometrik tekniklerle analiz edilmiştir ve parametreler 2023 yılındaki demiryolu taşımacılı̆ını tahmin etmekte kullanıımışlardır; ikinci olarak, Avrupa Birlig̈i'nden Türkiye'yle benzer yapıdaki ülkeler hiyerarşik kümeleme analiziyle belirlenmeye çalışııışır; ve üçüncü olarak, bu belirlenen ülkelere veri zarflama analizi uygulanmıştır. Çünkü mevcut altyapının etkin kullanılması da gelecek yatııı ihtiyaçlarıı planlamada önemlidir. Araştırmanın sonucunda değişkenler arasında anlamı pozitif bir ilişki bulunmuştur. Ticaret hacmindeki \%1'lik artış, demiryolu taşımacılığındaki yüklerde yaklaşık \%0,35'lik bir artışa neden olmaktadır. Ekonometrik analizlere ek olarak hiyerarşik kümeleme analiziyle Avrupa Birliği'nden Türkiye'yle benzer yapıdaki ülkeler belirlenmeye çalışılış ve aynı kümede yer alan ülkelerle veri zarflama analizi kullanılarak etkinlik kıyaslaması yapılmışır.

Bulgular- Ekonometrik analizlerin sonucunda, değișkenler arasında anlamı pozitif bir ilişki bulunmuştur. Ticaret hacmindeki \%1'lik artış, demiryolu taşımacılı̆ıındaki yüklerde yaklaşık \%0,35'lik bir artışa neden olmaktadır, ve sonuç olarak 2023'teki taşınan kargo miktarındaki artış \%85 olarak hesaplanmıştır. Kümeleme analizine göre ise Türkiye, Birleşik Kralıı, Fransa ve İtalya'nın olduğu gurupta yer almıştır ve veri zarflama analizine göre bu gruptaki en az etkin ülke konumundadır. 
Sonuç- Bu analizlerin sonucunda, ülkemizin 2023 yılında hedeflediği 1,17 trilyon dolarlık ticaret hacmine etkin bir şekilde hizmet edebilmesi için kısa dönemde etkinliği arttırıcı yatırımlara, uzun dönemde ise ciddi altyapı yatırımlarına ihtiyaç duyduğu tespit edilmiştir.

Anahtar Kelimeler: Demiryolu taşımacılığı, ticaret hacmi, etkinlik, yatırım.

JEL Kodları: C10, L92, L98

\section{GiRiş}

Ulaştırma karayolu, demir yolu, denizyolu, havayolu, boru hatları, iç suyolu ve bilgi iletişimi olmak üzere 7 alt sistem altında toplanmaktadır. Ancak mevcut ulaştırma ihtiyaçları ağırlıklı olarak kara, deniz ve hava gibi üç ortamda gerçekleştirilmektedir. Ulaştırmaya olan talebin bu üç ortama yönelmesinde, bu ortamların sağladığı ekonomik üstünlükler fark oluşturmaktadır (Altınok, 2011). Bu ekonomik üstünlükler ağırlıklı olarak maliyet ve zaman temelinde değerlendirilmektedir

Ancak günümüzde farklı ulaştırma sistemlerinin birbirlerine olan üstünlükleri azalmaya başlamıştır. Çünkü tedarik zinciri anlamında ulaştırma ağları büyümüş ve sistemler arası rekabet arttığı için alternatif taşıma sistemleri de ekonomik seçenekler halini almışlardır. Ayrıca teknolojik gelişmeler de çoğu sistemde taşıma maliyetlerini ve teslimat sürelerini düşürerek birbirlerine ikame sistem olmalarını sağlamıştır. Bu gelişmelerle beraber küreselleşen dünyada ulaştırma sistemlerinin tek başlarına önemleri azalmış ve birbirlerini tamamlayıcı özellikleri giderek artmaya başlamıştır. Tedarik zincirinde tüm sistemler birbirlerine muhtaç hale gelmeye başlamışlardır. Bu noktada kombine taşımacılık sistemleri daha da önem kazanmaya başlamıştır (Kaynak, 2002). Kara taşıma sistemlerinde kombine taşımacılığın en önemli destekleyicisi ise çevreci, ekonomik ve güvenli yapısıyla demiryolu taşımacılığıdır.

Son yıllarda demiryolu taşımacılığı daha da önem kazanmıştır. Bunun başlıca nedenleri, alternatif taşıma sistemi olan karayolu ulaştırmasının doyum noktasına ulaşması ve çevreyle ilgili duyarlılıkların artması olarak tanımlanabilmektedir. Ayrıca birim başına yakıt tüketiminin düşük olması nedeniyle havayı daha az kirletmesi, yüksek hızlarda seyir edebilmesine karşın kaza riskinin diğer alternatiflere göre düşük olması (İnan ve Demir, 2017) ve ölçek ekonomisi sağlaması da bu nedenlere dâhil edilebilmektedir (Woroniuk vd., 2012). Demiryolu taşımacılığı en çevre dostu ve en etkin taşıma modlarından biri olarak kabul edilmektedir (Song vd., 2015).

Yük ve yolcu taşımacılığı açısından düşünüldüğünde ise, karayolunun trafik yükünü azaltması, alternatif ulaştırma sistemlerine göre uzun dönemde fiyatının daha az değişmesi, karayollarında limitlerle sınırlanan yüksek tonajlı yüklere imkân tanıması, vagonların yüke göre düzenlenebilmesi, hava koşullarından etkilenmemesi ve yolcular için konforlu hizmet vermesi demiryolu taşımacılığının avantajlı yönleri olarak sıralanabilmektedir (Murat ve Şahin, 2010).

Türkiye'nin coğrafi olarak stratejik bir konumda yer aldığı sürekli vurgulanmakla beraber ülkenin coğrafi konumundan kaynaklı öneminin ülkenin kalkınmasında karşlık bulması ancak transit ağlar üzerindeki altyapı ihtiyaçlarına cevap verebilmesi ve çoklu ulaştırma türleri arasındaki güçlü bir bütünleşmeyi sağlayabilmesine bağlıdır (Çekerol ve Nalçakan, 2011). Intermodal taşımacılık da bu bütünleşmenin ürünlerinden biridir. Demiryolu ayağı düşünüldüğünde Türkiye ulusal ve uluslararası taşımacılıkta intermodal demiryolu taşımacılı̆̆ının oranının artması için gereken potansiyele ve fırsatlara sahiptir (Deveci ve Çavuşoğlu, 2013). Demiryolu taşımacılığı intermodal taşımacılık zincirinin bir düğüm noktası olarak düşünüldüğünden diğer sistemlerle birleşim ve paylaşım imkânlarının arttırılması önemlidir (Kasapoğlu ve Cerit, 2011).

Ayrıca Avrupa Birliği'nin sürdürülebilir kalkınma hedefleri doğrultusunda yeşil lojistik uygulamaları ön plana çıkmakta ve birim başına çevreye daha az zarar veren denizyolu ve demiryolu ulaştırma sistemleri önem kazanmaktadır (Tuna, 2011). Bu noktada, AB ulaştırma politikaları kapsamında tasarlanan ulaştırma koridoru projeleri ülkemizi de kapsamaktadır. Bunun bir gerekliliği olarak da demiryollarının geliştirilmesi ve denizyoluyla entegrasyonun güçlendirilmesi, ülkemizin bu fırsatlardan maksimum faydayı elde edebilmesi için hayati önem taşımaktadır. Ayrıca bu projeler demiryolu sektörünün tekrar canlandırılması ve etkin projeler içine dâhil edilmesi için önemli fırsatlardır (Saatçioğlu ve Kolbaşı, 2012)

Ülkemizde demiryolu sektörünün serbestleştirilmesi ve rekabete açılması teknoloji izlemeyi kolaylaştıracağı için gelişsmeleri daha da hızlandırabilir (Kabasakal ve Solak, 2009). Ayıca demiryollarının işletmelere açılması halinde, piyasaya girişte hat yapım maliyetleri yer almayacağı için yatırım maliyetleri de düşük olacaktır ve ikinci el demiryolu araçları varlık maliyetleri de düşeceği için yatırım riskleri düşecektir (Kabasakal ve Solak 2008). Ayrıca işletmelerin çoğalması demiryolu altyapısının etkin olarak işletilebilmesi için de faydalı olacaktır. 


\section{Şekil 1: Türkiye'nin Ticaret Hacmi ve Demiryoluyla Taşınan Toplam Tonaj}

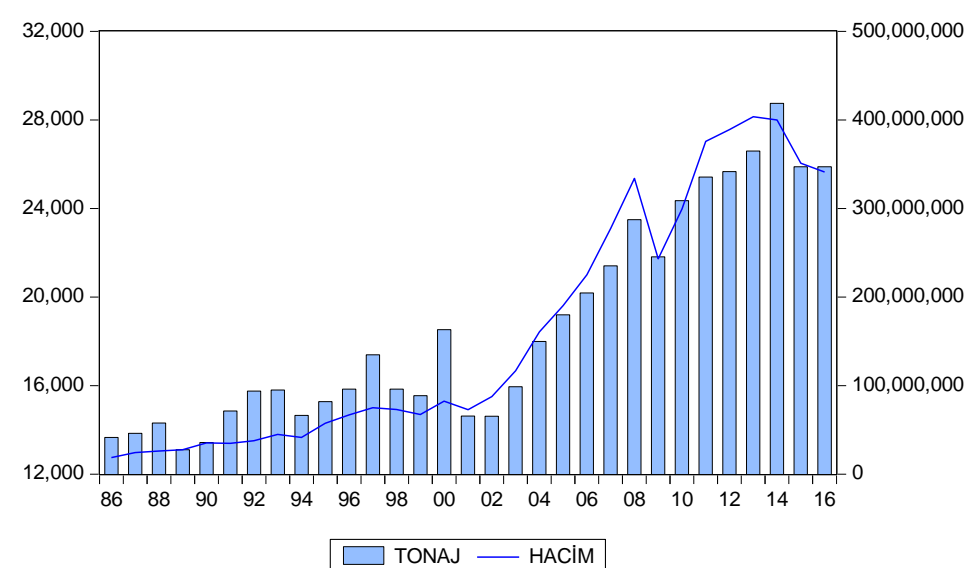

Kaynak: TüiK, 2017; World Bank, 2017a; World Bank, 2017b

Demiryolu taşımacılığı ekonomik, çevreci, güvenli ve hızlı olmasının yanında hem transit yüklere hizmet ederek hem de ülke içindeki ekonomik aktiviteleri destekleyerek ülke ekonomisine önemli katkılar sunmaktadır. Ülke içindeki ihracatçılarımızın ara mal ithalatı ve bitmiş ürün ihracatı faaliyetlerinde önemli bir maliyet kalemi olan taşımacılık masraflarında kayda değer düşüşler sağlayarak ihracatçılarımızın rekabetçi üstünlük kazanmalarına önemli katkıda bulunmaktadır. Ayrıca ticaret hacmi arttıkça demiryoluna olan talep de dolaylı olarak artacaktır. Şekil 1'de ticaret hacmi ve demiryoluyla taşınan yük miktarının grafiği sunulmuştur. Bu grafikten de görüldüğü gibi ticaret hacmi ve taşınan tonaj çoğunlukla beraber hareket etmektedirler ve ticaret hacmindeki düşüş demiryolu sektöründe de doğrudan hissedilmektedir.

İlgili literatür incelendiğinde benzer alanlarda yapılan çalışmalara rastlanmıştır ve bu çalışmada ortaya çıkması umulan pozitif ilişki doğrulanmıştır (Rao, 1978; Gargett ve Aroia, 1990; The Productivity Commission, 2006; Anderson ve Elger, 2012). Ihracat miktarı (değeri), ithalat miktarı (değeri), GSYiH ve GSMH gibi değişkenler taşımacılığa olan talebi arttırdıkları için, demiryolu taşımacılığına olan etkileri pozitif yönde gerçekleşmektedir. Başka bir deyişle demiryolu altyapısının durumu ülkelerin ekonmik faaliyetlerini destekleyici bir rol üstlenmektedir.

Bu noktada bu çalışma, Türkiye'deki ekonomik aktiviteler ile demiryolu taşımacılığı arasındaki ilişkiyi tespit ederek ülkemizin demiryolu altyapısının 2023 vizyonu çerçevesinde hedeflediği 1,17 trilyon dolarlık ticaret hacmi hedefine ne kadar hazır olduğunu belirlemeyi amaçlamaktadır. Ekonometrik ilişkinin yanında altyapının etkin kullanımı da önemli olduğu için çeşitli etkinlik ölçümleriyle de sonuçlar desteklenmektedir ve öneriler sunulmaktadır.

Çalışmanın hedefleri doğrultusunda 2. bölümde çalışmanın yöntemleri tanıtılmaktadır. Çalışmanın modeli 3 . bölümde açıklandıktan sonra 4. bölümde analizlerden elde edilen bulgular sunulmaktadır. Daha sonra çalışma 5. bölümdeki tartışma ve sonuç bölümüyle sona ermektedir.

\section{YÖNTEM}

Çalışmada kullanılan yöntemler sırasıyla korelasyon analizi, regresyon analizi, hiyerarşik kümeleme analizi ve veri zarflama analizidir. Yöntemler hakkında tanıtıcı kısa bilgiler aşağıdaki bölümlerde sunulmaktadır.

\subsection{Korelasyon Analizi}

Korelasyon analizi iki değişken arasındaki doğrusal ilişkinin yönünü ve kuvvetini gösterir. Değişkenlerin kovaryanslarının standart sapmalarına bölünmeleriyle elde edilir. Korelasyon değeri +1 ve -1 aralığında değişmekle birlikte mutlak değer 1'e ne kadar yakın bir değer elde edilirse ilişkinin o kadar kuvvetli olduğu anlaşılmaktadır (Chang, 2014:78). Korelasyonun da en yaygın kullanılan yöntemleri Pearson ve Spearman korelasyonlarıdır. Pearson genel olarak normal dağılımlı verilere uygulanırken Spearman normal dağılım özelliği göstermeyen verilere uygulanmaktadır.

\subsection{Regresyon Analizi}

Regresyon analizi bir bağımlı değişkenin bir ya da daha fazla sayıdaki bağımsız değişkene olan bağımlığını ölçmek için kullanılan bir yöntemdir. Bağımlı değişken ekonometrik bir model oluşturularak açıklayıcı değişkenlerle açıklanmaya çalışıır (Gujarati, 2004:18). Bir bağımlı ve bir bağımsız değişkenden oluşan basit bir regresyon denklemi (1)'deki gibi kurulmaktadır. $Y_{i}$ bağımlı değişkendir, $X_{i}$ bağımsız değişkendir ve $u_{i}$ de hata terimidir. Beta ${ }_{1}$ sabit terimi ifade ederken Beta ${ }_{2}$ ise bağımsız değişkenin katsayısını gösterir. 


$$
Y_{i}=\beta_{1}+\beta_{2} X_{i}+u_{i}
$$

Bu çalışmada tercih edilmiş olan log-log regresyon modelinde (2) ise bağımlı değişkenin bağımsız değişkene göre esnekliği elde edilir. Bağımsız değişkendeki yüzdesel değişimin bağımlı değişkende meydana getirdiği yüzdesel değişimi ifade eder (Gujarati, 2004:176). Logaritmik verilerin kullanılmasının bir diğer avantajı da serileri sürekli hale getirerek işlenmelerini kolaylaştırmasıdır.

$$
\ln Y_{i}=\ln \beta_{1}+\beta_{2} \ln X_{i}+u_{i}
$$

\subsection{Kümeleme Analizi}

Bireyleri ya da olguları farklı gruplara ayıran ve verileri teknik özelliklerine göre gruplandıran çok değişkenli bir analiz tekniğidir. Birbirine benzeyen nesneler aynı kümede yer toplanır ve böylece her bir küme içindeki homojenlik ve kümeler arasındaki heterojenlik maksimum düzeye çıkar (Karagöz, 2016:899). Kümeleme analizi, sosyal bilimler, eğitim, tıp, biyoloji, psikoloji, sosyoloji, arkeoloji, pazarlama gibi bilim alanlarında yoğun olarak kullanılmaktadır. Kümeleme analizinde değişken sayısı arttıkça veri sayısının da artması gerekecektir. Veri sayısının değişken sayısının yaklaşık 3-4 katı olması analizın güvenilirliği açısından daha iyi olacaktır.

\subsection{Veri Zarflama Analizi}

Charnes vd. (1978) tarafından geliştirilmiş olan veri zarflama analizi, en çok kullanılan doğrusal programlama tabanlı matematiksel etkinlik ölçümü tekniklerindendir. Bu teknikte etkinlik öncüleri oluşturulur ve ilgili etkinliklerin tahmini için karar noktaları kullanılır. Öncülerin üstünde olan birimlerin etkin, altında konumlanan birimlerin ise etkin olmadığı kabul edilir. Kullanılan en yaygın yöntemler CCR (ölçeğe göre sabit getiri) ve BCC (ölçeğe göre değişken getiri) modelleridir. Charnes vd. (1978) tarafından matematiksel olarak modellenen ilk veri zarflama analizi modeli CCR'dir. Bu model girdiler ve çıktılar arasındaki ölçeğe göre sabit getiri varsayımının ilişkisini temel alır. Banker vd. (1984) tarafından geliştirilen BCC yöntemi ise CCR modelinin varsayımlarında değişiklik yapılarak elde edilmiş bir modeldir ve temelde ölçeğe göre değişken getiri varsayımına dayanır.

Veri zarflama analizi, çalışmanın amacı doğrultusunda girdi odaklı veya çıktı odaklı olarak yapılandırılır. Eğer amaç fazla kaynak kullanan birimlerin tespiti ise odaklanılması gereken girdi odaklı modeldir. Ancak eğer amaç çıktı artırımı ise uygun model çıktı odaklı modeldir (Cook vd., 2014).

\section{ARAŞTIRMANIN MODELI}

Araştırmanın modeli iki farklı kanattan toplanan bilgilerin ortak havuzda yorumlanmasıyla oluşmaktadır. İlk olarak araştırmanın temelini de oluşturan ekonomik aktiviteler ve demiryolu taşımacılığı ilişkisi ekonometrik yöntemlerle analiz edilmektedir. Daha sonra buradan elde edilen bilgilere farklı açıdan elde edilen etkinlik bilgileri de eklenerek ortak bir sonuca ulaşılmaktadır. Şekil 2'de görüldüğü gibi analiz ilk olarak toplam ticaret hacmiyle demiryoluyla taşınan yük miktarı arasındaki ekonometrik ilişkiyi inceleyerek başlamaktadır. Bu noktada korelasyon ve regresyon analizleri kullanılmaktadır. Daha sonra ekonomik aktivitelerin olası pozitif etkilerinin yanında, mevcut altyapının verimli kullanılıp kullanılmadığının da yatırım ve düzenlemeler için önemli olduğu düşünülerek veri zarflama analiziyle etkinlik ölçümü yapılmıştır. Veri zarflama analizinden önce ise etkinlik değerlendirmelerinin benzer özellikteki ülkelerle yürütülebilmesi için hiyerarşik kümeleme analizi kullanılarak homojen bir küme oluşturulmaya çalışılmaktadır. Tüm bu yöntemlerden elde edilen bilgiler ışığında da bulgular yorumlanmakta ve sonuçlar öneriler eşliğinde sunulmaktadır.

\section{Şekil 2: Çalışmanın Modeli}

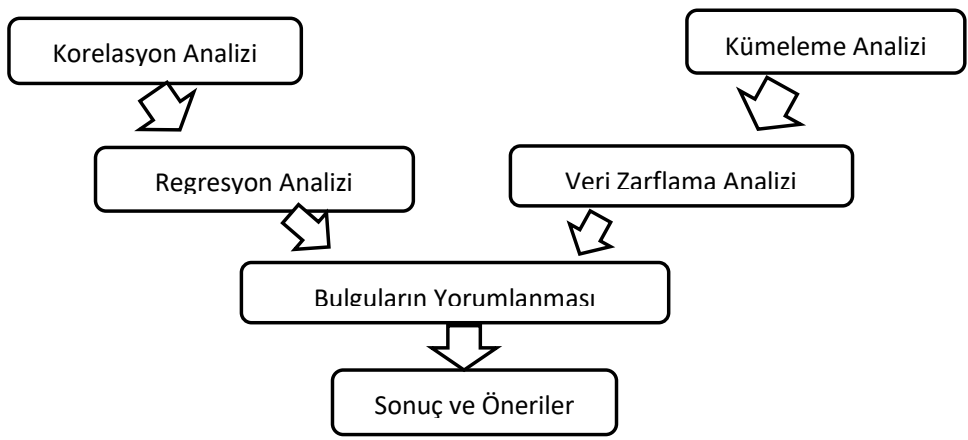




\section{BULGULAR}

Bu kısımda korelasyon, regresyon, hiyerarşik kümeleme ve veri zarflama analizlerinde kullanılan veriler ve analizlerin sonuçları sırasıyla sunulmaktadır.

\subsection{Korelasyon Analizi Sonuçları}

Korelasyon ve regresyon analizleri için kullanılacak veri seti Tablo 1'de gösterilmiştir. Bu analizlerde Türkiye'nin toplam ticaret hacmiyle demiryoluyla taşınan toplam tonaj değişkenleri arasındaki ilişki incelenecektir. Serilerin logaritması alınarak daha işlenebilir hale dönüştürülmüşlerdir ve sürekli hale gelmeleri sağlanmıştır. Zaman serisi analizlerinde tahmincinin sahte sonuçlar vermesinin önüne geçmek için ve tahminleme gücünü arttırmak için serilerin durağan olması gerekmektedir. Bu yüzden serilere birim kök testi uygulandıktan sonra ilk farkları alınarak seriler durağan hale getirilmişlerdir. Logaritmik ve farkı alınmış serilerin tanımlayıcı istatistikleri de Tablo 1'de gösterilmektedir.

Tablo 1: Değişkenlerin Tanımlayıcı İstatistikleri

\begin{tabular}{|c|c|c|c|c|c|c|}
\hline & Tonaj (bin t) & Hacim (bin\$) & Ln Tonaj & Ln Hacim & $\Delta \operatorname{Ln}$ Tonaj & $\Delta \mathrm{Ln}$ Hacim \\
\hline Gözlem Sayısı & 31 & 31 & 31 & 31 & 30 & 30 \\
\hline Ortalama & 18696.06 & $1.61 \mathrm{E}+08$ & 9.806005 & 18.45703 & 0.021317 & 0.097041 \\
\hline Medyan & 15941.00 & 82277727 & 9.676650 & 18.22561 & 0.036075 & 0.132989 \\
\hline Maksimum & 28747.00 & $4.03 E+08$ & 10.26629 & 19.81560 & 0.175843 & 0.326406 \\
\hline Minimum & 13103.00 & 18561497 & 9.480596 & 16.73660 & -0.236814 & -0.317760 \\
\hline Standart Sapma & 4801.950 & $1.38 \mathrm{E}+08$ & 0.245564 & 1.003268 & 0.083450 & 0.153307 \\
\hline Çarpıklık (Skewness) & 0.654666 & 0.619333 & 0.459582 & -0.019827 & -0.999956 & -0.623406 \\
\hline Basıklık (Kurtosis) & 1.975052 & 1.758600 & 1.755801 & 1.603264 & 4.445795 & 2.993874 \\
\hline Jarque-Bera İstatistiği & 3.571285 & 3.972351 & 3.090823 & 2.521908 & 7.612462 & 1.943224 \\
\hline JB Olasılığı & 0.167689 & 0.137219 & 0.213224 & 0.283384 & 0.022232 & 0.378472 \\
\hline
\end{tabular}

Kaynak: TüiK, 2017; World Bank, 2017a; World Bank, 2017b

Birim kök testi için kullanılan en yaygın yöntemlerden biri Augmented Dickey-Fuller testidir. Hacim ve tonaj değişkenlerine test uygulandığında Tablo 2'de görüldüğü gibi serilerin birim kök içerdikleri görülmüştür. İlk farkları alındığında ise seriler durağan hale gelmektedir. Bundan sonraki aşama ise korelasyon ve regresyon analizlerine geçilmesidir.

Tablo 2: ADF Birim Kök Testi Sonuçları

\begin{tabular}{|c|c|c|c|}
\hline & & Intercept & Trend and Intercept \\
\hline \multicolumn{4}{|l|}{ Seviye } \\
\hline In HACIM & & -1.4073 & -1.6152 \\
\hline In TONAJ & & -0.7096 & -2.7226 \\
\hline \multicolumn{4}{|l|}{ Birinci Farklar } \\
\hline$\triangle \mathrm{In}$ HACIM & & $-5.4547 * * *$ & $-5.4893 * * *$ \\
\hline \multirow[t]{2}{*}{$\triangle \ln$ TONAJ } & & $-6.5229 * * *$ & $-6.4230 * * *$ \\
\hline & $1 \%$ & -3.6701 & -4.2967 \\
\hline \multirow[t]{2}{*}{ Kritik Değerler } & $5 \%$ & -2.9639 & -3.5683 \\
\hline & $10 \%$ & -2.6210 & -3.2183 \\
\hline
\end{tabular}

Anlamlılık Seviyeleri $=* 10 \%, * * 5 \%, * * * 1 \%$

Korelasyon analizinden önce farkı alınmış serilerin grafiksel ilişkilerini görmek çıkacak sonuç hakkında bir fikir sunacaktır. Şekil 3'de görüldüğü gibi serilerin arasındaki pozitif yönlü kuvvetli bir ilişki vardır. Teoriye de uygun olarak ekonomik aktiviteler arttığında demiryolu taşımacılığı da artmaktadır. Ancak bu ilişkinin ekonometrik olarak kuvveti ve anlamlılı̆ı korelasyon testiyle belirlenebilmektedir. 


\section{Şekil 3: Farkı Alınmış Logaritmik Değişkenlerin Grafiği}

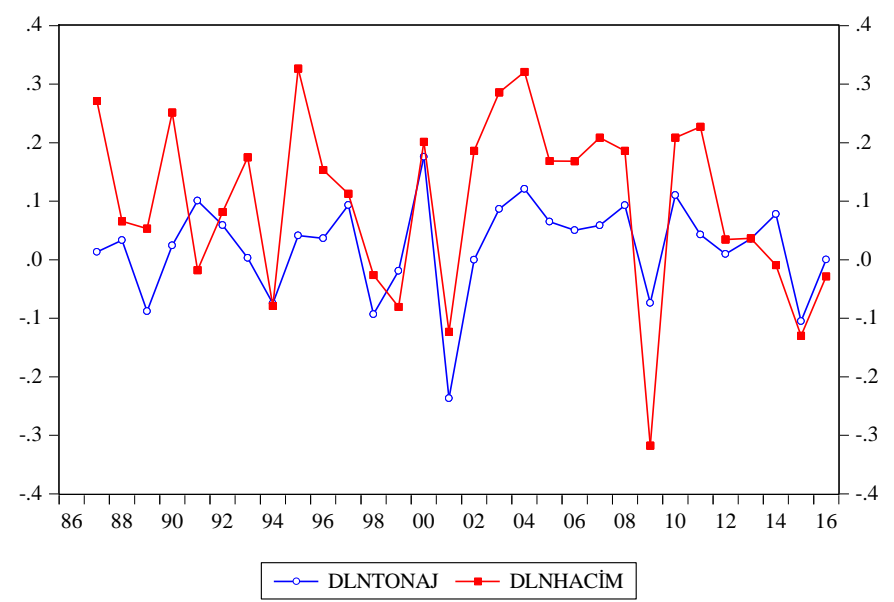

Yöntem kısmında da belirtildiği gibi normal dağılımlı serilerin korelasyon analizlerinde Pearson'un korelasyon tekniğinin kullanılması daha uygun olmaktadır. Ancak Tablo 1'deki Jarque-Bera olasılıkları incelendiğinde Hacim değişkeninin normal dağııım özelliklerine sahipken Tonaj değişkeninin bu özelliklere sahip olmadığı görülmektedir. Bu yüzden seriler arasındaki korelasyon hem Pearson hem de Spearman yöntemleriyle test edilmiş ve sonuçlar Tablo 3'de sunulmuştur.

Tablo 3: Korelasyon Analizi Sonuçları

\begin{tabular}{lll}
\hline & $\begin{array}{l}\Delta \text { InTONAJ } \\
\text { (Pearson) }\end{array}$ & $\begin{array}{l}\Delta \text { InTONAJ } \\
\text { (Spearman) }\end{array}$ \\
\hline & 0.636461 & 0.577308 \\
InHACiM & $(4.366395)$ & $(3.741248)$ \\
& 0.0002 & 0.0008 \\
\hline
\end{tabular}

Test sonuçlarına göre ticaret hacmi ve demiryoluyla taşınan yük tonajı arasında orta derecede pozitif anlamlı korelasyon katsayıları tespit edilmiştir. Bu sonuçlar iki değişkenin aynı yönde hareket ettiğini göstermektedir. Ticaret hacmi artarken tonaj da artmakta, ticaret hacmi azalırken tonaj da azalmaktadır. Sonuçlar teoriye uygundur fakat korelasyon analizi aralarındaki bir nedenselliği ve etkileşimi göstermediği için regresyon analizini de uygulamak faydalı olacaktır.

\subsection{Regresyon Analizi Sonuçları}

Regresyon analizi, daha önce de değinildiği gibi, bağımlı değişkenlerdeki değişimin ne kadarının bağımsız değişkenlerdeki değişimlerden kaynaklandığını tespit etmek için kullanılan en yaygın ekonometrik yöntemlerden birdir. Bizim modelimiz demiryoluyla taşınan toplam tonaj bağımlı değişken, toplam ticaret hacmi bağımsız değişken olacak şekilde tasarlanmış ve (3)'te model gösterilmiştir. Değişkenlerin işlenmelerinin kolaylaşması ve sürekli hale gelmelerinin sağlanması için denklem logaritmik verilerle oluşturulmuştur. Ayrıca korelasyon bölümünde gösterildiği şekilde serilerin farkı alınarak durağanlaştırılmışlardır.

$$
\triangle \operatorname{lnTONAJ} J_{i}=\ln \beta_{1}+\beta_{2} \Delta \ln H A C I M_{i}+u_{i}
$$

Ekonometrik program aracılığıyla tahminlenen sonuçlar Tablo 4'te sunulmuştur. $F$ istatistiği modelin bir bütün olarak anlamlılı̆ını göstermektedir ve olasılık değeri incelendiğinde modelin bir bütün olarak anlamlı olduğu görülmektedir. Değişkenlerin anlamlılıkları incelendiğinde sabit değişkeninin anlamsız ama hacim değişkeninin anlamlı olduğu olasılık değerlerinden tespit edilebilmektedir. Modelin açıklama gücü R-kare değerinin ise 0,40 olduğu, yani bağımsız değişkenlerdeki değişimin bağımlı değişkendeki değişimlerin \%40'ını açıkladığı söylenebilmektedir. Anlamlı bağımsız değişkenimiz olan hacim değişkeninin katsayısına göre de hacimde meydana gelen \%1'lik bir değişme, tonajda \% $0.35^{\prime}$ lik bir değişmeye neden olmaktadır. Başka bir deyişle ticaret hacmi \%1 arttığında, demiryoluyla taşınan toplam yük miktarı \%0,35 oranında artmaktadır. Bundan sonraki adım, bu tahminleme sonuçlarının güvenilirliğini test etmek için modelin artıklarına otokorelasyon, seri korelasyon, değişen varyans ve normallik testlerinin uygulanmasıdır. 
Tablo 4: Regresyon Tahmin Sonuçları

\begin{tabular}{|c|c|c|c|c|}
\hline \multicolumn{5}{|c|}{ Bağımlı Değişken: $\Delta$ In TONAJ } \\
\hline Değişken & Katsayı & Std. Hata & t-i̇statistiği & Olasılık \\
\hline $\mathrm{C}$ & -0.012302 & 0.014224 & -0.864885 & 0.3945 \\
\hline$\triangle$ In HACIM & 0.346444 & 0.079343 & 4.366395 & 0.0002 \\
\hline R-kare & 0.405083 & \multicolumn{2}{|c|}{ F-istatistiği } & 19.06540 \\
\hline Ayarlanmış R-kare & 0.383836 & \multicolumn{2}{|c|}{ Olasılık (F-istatistiği) } & 0.000156 \\
\hline
\end{tabular}

Otokorelasyon testinde 16 gecikmeye bakılmış ve tüm gecikme turlarında boş hipotez reddedilmemiştir. Bu testteki boş hipotez otokorelasyon problemi olduğunu reddeden hipotezdir ve Tablo 5'te görüldüğü gibi denklemde bu problem mevcut değildir.

Tablo 5: Oto Korelasyon Testi Sonuçları

\begin{tabular}{llllllllll}
\hline Gecikme & AC & PAC & Q-ist. & Olasılık & Gecikme & AC & PAC & Q-íst. & Olasılık \\
\hline 1 & -0.104 & -0.104 & 0.3575 & 0.550 & 9 & 0.134 & 0.106 & 7.0519 & 0.632 \\
2 & -0.266 & -0.280 & 2.7881 & 0.248 & 10 & -0.258 & -0.132 & 10.255 & 0.418 \\
3 & 0.125 & 0.066 & 3.3403 & 0.342 & 11 & -0.095 & -0.147 & 10.711 & 0.468 \\
4 & -0.082 & -0.146 & 3.5875 & 0.465 & 12 & 0.086 & -0.064 & 11.109 & 0.520 \\
5 & 0.036 & 0.072 & 3.6373 & 0.603 & 13 & -0.098 & -0.136 & 11.648 & 0.557 \\
6 & 0.164 & 0.116 & 4.7074 & 0.582 & 14 & 0.209 & 0.158 & 14.259 & 0.431 \\
7 & -0.138 & -0.067 & 5.4992 & 0.599 & 15 & -0.126 & -0.182 & 15.274 & 0.432 \\
8 & 0.129 & 0.194 & 6.2273 & 0.622 & 16 & -0.043 & 0.159 & 15.401 & 0.495 \\
\hline
\end{tabular}

Bir diğer test olan LM seri korelasyon testi sonuçları Tablo 6'da sunulmuştur. Örneklem sayısı küçük olduğu için F testi temel alınarak yorum yapılmaktadır. Bu testin olasııık sonucuna göre boş hipotez olan seri korelasyon olmadığı hipotezi reddedilememektedir. Yani denklemimizde bir seri korelasyon problemi bulunmamaktadır.

Tablo 6: LM Seri Korelasyon Testi Sonuçları

\begin{tabular}{llll}
\hline F-istatistiği & 1.439313 & Olasılık F(2,26) & 0.2554 \\
Göz*R-kare & 2.990406 & Olasılık Ki Kare & 0.2242 \\
\hline
\end{tabular}

Denklemlerin artıklarında değişen varyans problemimin olması tahmincinin tahminleme gücünde önemli problemler oluşturmaktadır. Bu sorunun tespiti için kullanılan en yaygın testlerden biri de White testidir. Bu test değişkene göre değişen varyans olup olmadığını tespit etmek için kullanılır. Testin sonuçları Tablo 7'te sunulmuştur ve bu testte de $\mathrm{F}$ testine bakılarak yorum yapılmaktadır. Sonuçlara göre boş hipotez olan değişen varyans sorunu olmadığı hipotezi reddedilememiştir. Dolayısıyla denklemimizde değişen varyans problemi bulunmamaktadır.

Tablo 7: White Değişen Varyans Test Sonuçları

\begin{tabular}{llll}
\hline F-istatistiği & 1.164383 & Olasılık F(2,27) & 0.3273 \\
Göz*R-kare & 2.382063 & Olasılık Ki-kare & 0.3039 \\
\hline
\end{tabular}

Tüm bu testlere ek olarak, artıkların normal dağılım özellikleri göstermesi de tahmincinin sağlığı açısından gerekli bir durumdur. Bu durumu test etmek için Jarque-Bera testi kullanılan en yaygın testlerden biridir. Bu testin sonuçları Tablo 8'de gösterilmiştir ve boş hipotez olan artıkların normal dağıldığı hipotezi, JB olasılığına göre reddedilememiştir. Yani denklemin artıkları normal dağılım özellikleri göstermektedir.

Tablo 8: Normallik Testi Sonuçları

\begin{tabular}{ll}
\hline Çarpıklık (Skewness) & -0.440132 \\
Basıkık (Kurtosis) & 3.679422 \\
Jarque-Bera & 1.545600 \\
JB Olasılığı & 0.461718 \\
\hline
\end{tabular}


Regresyon denkleminin artıkları gerekli varsayımları sağladığına göre denklem kullanımına geçilebilir. Tahmin sonuçlarımıza göre sabit değişkenimiz anlamsız çıkmıştı ve toplam ticaret hacmini temsi eden Hacim değişkenindeki \%1'lik değişme demiryoluyla taşınan yükün toplam tonajını temsil eden Tonaj değişkeninde yaklaşık \%0,35'lik bir değişime neden olmaktaydı. Tüm bu bilgiler doğrultusunda Türkiye'nin 2023 yılındaki hedefi olan 1,17 trilyon dolarlık ticaret hacmine ulaşabilmesi için bugünkü ticaret hacminin \%243 oranında artması gerekmektedir. Tablo 9'da görüldüğü gibi, regresyon denklemimizdeki katsayılara göre de hacimdeki bu artış tonajda \%85'lik bir artışa neden olacaktır.

Tablo 9: Tahmin Sonuçlarına Göre 2023 Yılına Kadar Demiryolu Yük Artışı

\begin{tabular}{ll}
\hline 2016 Yılındaki Ticaret Hacmi & $\$ 341.147 .818 .855,00$ \\
2023 Yılındaki Ticaret Hacmi Hedefi & $\$ 1.170 .000 .000 .000,00$ \\
2016 Yılına Göre 2023 Yılındaki Ticaret Hacmi Artışı & $243 \%$ \\
Regresyona Göre Demiryoluyla Taşınan Yük Miktarı Artışı & $85 \%$ \\
\hline
\end{tabular}

Regresyon sonuçlarına göre altyapıda büyük yatırımlara ihtiyaç duyulacağı görülmektedir. Ancak bu noktada mevcut altyapının ne kadar etkin kullanıldığı önemlidir. Çünkü eğer bir verimsizlik söz konusuysa büyük yatırımlardan ziyade verimliliği arttıracak yatırımlar yeterli olacaktır. Bu bağlamda kümeleme analizi ile Avrupa Birliği üyesi ülkelerden Türkiye ile benzerlik gösteren ülkeler tespit edilip veri zarflama analizi ile etkinlikleri kıyaslanacaktır.

\subsection{Kümeleme Analizi Sonuçları}

Kümeleme analizi için Avrupa Birliği üyesi 28 ülke ile beraber Türkiye de dâhil edilerek hiyerarşik kümeleme tekniği kullanılmıştır. Kümeleme analizi için de demiryolu kullanımını ve boyutunu etkileyebilecek faktörler olarak, gayri safi yurt içi hâsıla, ürün ithalatı, ürün ihracatı, nüfus ve ülke yüz ölçümü değişkenleri seçilmiştir. Değişkenler analiz programına aktarıldıktan sonra daha sağlıklı sonuçlar elde edilmesi adına 0 ve 1 arasında standartlaştırıımıştır.

Ward yöntemi kullanılarak oluşturulan hiyerarşik kümelemelerin sonuçları Şekil 4'teki dendogram aracılığıyla gösterilmiştir. Bu teknikte mesafenin temel alındığı noktaya göre kümeler oluştuğu için küme sayısı araştırmanın yorumlamasına bırakılmaktadır. Bu yüzden mesafe kırmızı şerit ile belirtilen noktadan itibaren temel alınarak 4 küme oluşturulması uygun bulunmuştur.

Şekil 4: Hiyerarşik Kümeleme Sonuçlarının Dendogram İle Gösterimi

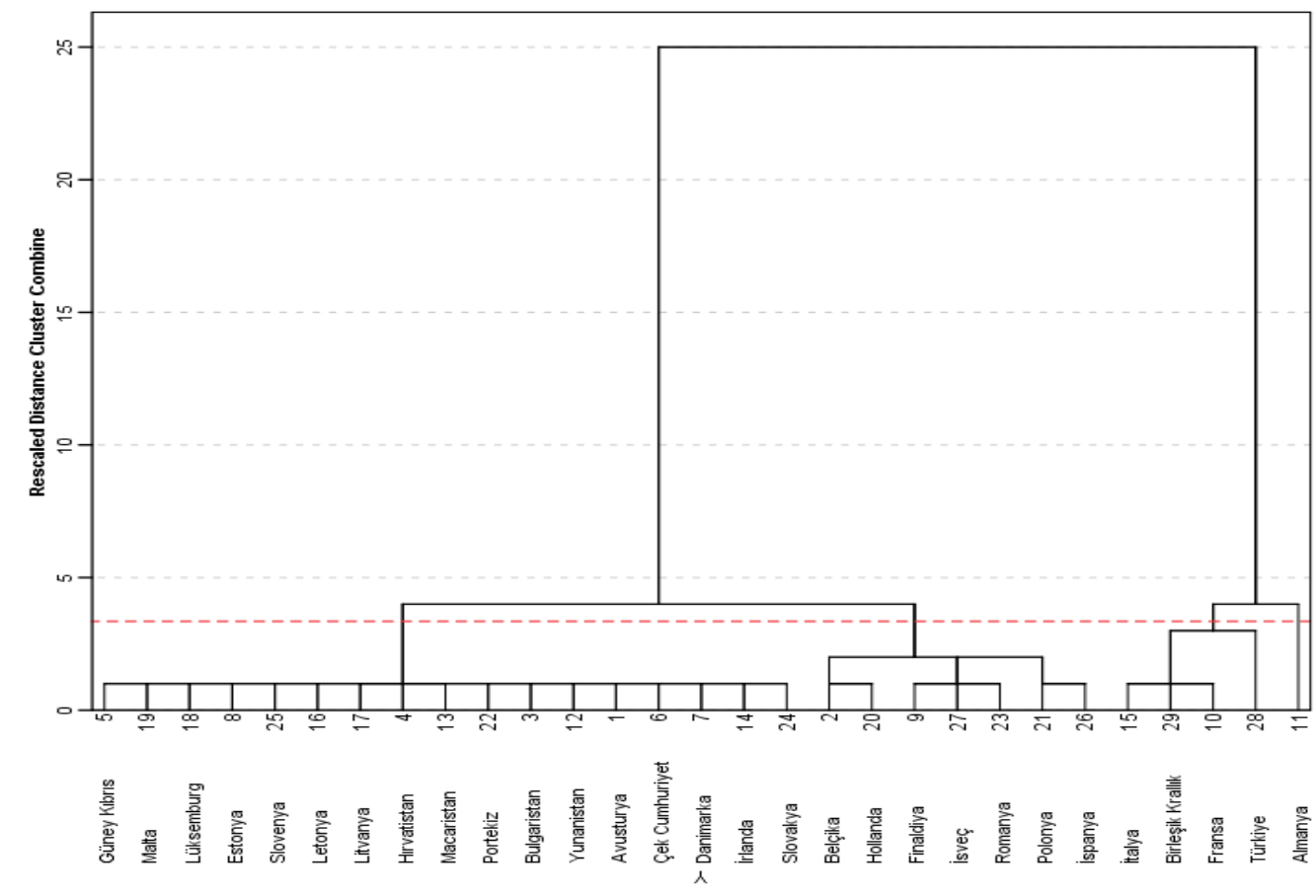


Oluşturulması uygun görülen bu 4 kümenin elemanları Tablo 10'da gösterilmiştir. Türkiye bu hiyerarşik kümelemeye göre, Birleşik Krallık, Fransa ve İtalya'nın da bulunduğu 3. kümede yer almaktadır.

Tablo 10: Ülkelerin Kümelere Göre Dağılımı

\begin{tabular}{|c|c|c|c|c|c|}
\hline Küme 1 & & & Küme 2 & Küme 3 & Küme 4 \\
\hline Avusturya & Kıbrıs & Slovakya & Belçika & Birleşik Krallık & Almanya \\
\hline Bulgaristan & Letonya & Slovenya & Finlandiya & Fransa & \\
\hline Çek Cumhuriyeti & Litvanya & Yunanistan & Hollanda & İtalya & \\
\hline Danimarka & Lüksemburg & & İspanya & Türkiye & \\
\hline Estonya & Macaristan & & İsveç & & \\
\hline Hırvatistan & Malta & & Polonya & & \\
\hline İrlanda & Portekiz & & Romanya & & \\
\hline
\end{tabular}

Kümelerin tanımlayıcı istatistikleri Tablo 11 'de gösterilmektedir. Her bir kümedeki ülkelerin sayısı, ortalama değerleri, standart sapmaları, minimum değerleri ve maksimum değerleri tabloda sunulmuştur.

Tablo 11: Kümelerin Tanımlayıcı İstatistikleri

\begin{tabular}{|c|c|c|c|c|c|c|}
\hline & & GSYiH (\$) & Ürün İthalatı (\$) & Ürün İhracatı (\$) & Nüfus (kişi) & Alan (bin $\mathrm{km}^{2}$ ) \\
\hline & Ortalama & 126054464941,94 & 54369052034,71 & 55731788794,71 & 5166690,06 & 58472,71 \\
\hline & Adet & 17 & 17 & 17 & 17 & 17 \\
\hline \multirow[t]{5}{*}{1} & Std. Sapma & 118669454068,48 & 46099845396,57 & 53636391193,26 & 3758538,41 & 36824,66 \\
\hline & Minimum & 10999047580,00 & 6197865170,00 & 2962396470,00 & 436947,00 & 320,00 \\
\hline & Maksimum & 390800000000,00 & 157746000000,00 & 162788000000,00 & 10847334,00 & 128900,00 \\
\hline & Ortalama & 556337571428,57 & 237503222952,86 & 245903063395,71 & 21123151,57 & 258807,14 \\
\hline & Adet & 7 & 7 & 7 & 7 & 7 \\
\hline \multirow[t]{5}{*}{2} & Std. Sapma & 357357334565,77 & 165346423242,47 & 188366183986,01 & 15322936,16 & 177169,25 \\
\hline & Minimum & 187592000000,00 & 60826811560,00 & 57566548300,00 & 5495096,00 & 30280,00 \\
\hline & Maksimum & 1237260000000,00 & 505067000000,00 & 571436000000,00 & 46443959,00 & 500210,00 \\
\hline & Ortalama & 1958993000000,00 & 453160500000,00 & 378811250000,00 & 68161591,00 & 463314,25 \\
\hline & Adet & 4 & 4 & 4 & 4 & 4 \\
\hline \multirow[t]{5}{*}{3} & Std. Sapma & 804311014336,29 & 195852765948,47 & 161904629259,28 & 8041226,88 & 243965,22 \\
\hline & Minimum & 863712000000,00 & 198618000000,00 & 142530000000,00 & 60600590,00 & 241930,00 \\
\hline & Maksimum & 2647900000000,00 & 636409000000,00 & 501220000000,00 & 79512426,00 & 769630,00 \\
\hline & Ortalama & 3477800000000,00 & 1055490000000,00 & 1337850000000,00 & 82667685,00 & 348900,00 \\
\hline & Adet & 1 & 1 & 1 & 1 & 1 \\
\hline \multirow[t]{5}{*}{4} & Std. Sapma & $\cdot$ & . & $\cdot$ & . & $\cdot$ \\
\hline & Minimum & 3477800000000,00 & 1055490000000,00 & 1337850000000,00 & 82667685,00 & 348900,00 \\
\hline & Maksimum & 3477800000000,00 & 1055490000000,00 & 1337850000000,00 & 82667685,00 & 348900,00 \\
\hline & Ortalama & 598209810177,76 & 188005294141,03 & 190339117398,96 & 20738628,55 & 173623,55 \\
\hline & Adet & 29 & 29 & 29 & 29 & 29 \\
\hline \multirow[t]{3}{*}{$\mathrm{T}$} & Std. Sapma & 895162699876,91 & 244119227250,72 & 275604968251,94 & 25682599,37 & 191096,61 \\
\hline & Minimum & 8022638722,00 & 3422950000,00 & 994850000,00 & 582972,00 & 2590,00 \\
\hline & Maksimum & 3477800000000,00 & 1055490000000,00 & 1337850000000,00 & 82667685,00 & 769630,00 \\
\hline
\end{tabular}

Kaynak: World Bank, 2017c; World Bank, 2017d; World Bank, 2017e; World Bank, 2017f; World Bank, 2017g. 


\subsection{Veri Zarflama Analizi Sonuçları}

Hiyerarşik kümeleme sonuçlarına göre Türkiye, Birleşik Krallık, İtalya ve Fransa'dan oluşan 4 elemanlı kümede yer almaktadır. Bazı yönlerden Türkiye'ye denk bu ülke grubu tespit edildikten sonra bir etkinlik analizi olan veri zarflama analizi kullanılarak denklerine göre Türkiye'nin demiryolu kullanımında ne derecede etkin olduğu tespit edilmeye çalışılmaktadır. Bunun belirlenmesi için ülke içindeki toplam demiryolu uzunluğu girdi olarak ve toplam taşınan yük miktarı ton-km bazında çıktı olarak modele dahil edilmiştir. Yöntem kısmında da değinildiği gibi, mevcut girdiyle elde edilebilecek çıktıyı belirleyebilmek için çıktı odakı CCR (ölçeğe göre sabit getiri) modeli kullanılmıştır. Analizde kullanılan ham veri, etkinlik değeri ve projeksiyon değerleri Tablo 12 'de sunulmuştur.

Tablo 12: VZA İçin Ham Data ve Analiz Sonuçları

\begin{tabular}{lllll}
\hline KVB Birimi & MTKM & Uzunluk & CCR O Değeri & BTKM Projeksiyonu \\
\hline Fransa & 34,252 & 28765 & 0,877 & 39,024 \\
Italya & 20,781 & 17041 & 0,898 & 23,118 \\
Türkiye & 10,178 & 10131 & 0,740 & 13,744 \\
Birleşik Krallık & 21,990 & 16209 & 1 & 21,990 \\
\hline
\end{tabular}

Kaynak: Eurostat, 2017

Sonuçlara göre 4 ülke içinde Birleşik Krallık en etkin ülke olarak öne çıkmaktadır. Onu sırasıyla İtalya ve Fransa izlemektedir. Türkiye ise $0,74^{\prime} l u ̈ k$ etkinlik değeriyle bu ülke grubundaki en etkin olmayan ülke konumunda yer almaktadır. Tabloda yer alan projeksiyon değerleri ise, en etkin ülke baz alındığında diğer etkin olmayan ülkelerin mevcut altyapılarıyla ne kadar daha fazla taşımacılık yapabileceklerini önermektedir. Türkiye'nin projeksiyon değerine göre şuanda 10,178 milyar ton-km olan demiryolu yük taşımacılığının, mevcut altyapıyla 13,744 milyar ton-km seviyelerinde yapılabilmesi gerekmektedir.

\section{SONUÇ}

Demiryolu taşımacılı̆̆ı hem birim başına taşıma maliyetindeki avantajıyla, hem de karayolu taşımacılığına göre daha çevreci yapısıyla önemli bir konumda yer almaktadır.Daha önce de değinildiği gibi bu çalışmanın amacı, Türkiye'nin ekonomik aktiviteleriyle demiryolunda taşınan yük miktarı arasındaki ilişkiyi belirleyip, ülkemizin 2023 vizyonundaki hedeflerine ulaşma sürecindeki olası talep artış miktarını tespit ederek gerekli yatırım miktarlarının belirlenmesine katkıda bulunmaktır. Bu doğrultuda ilk olarak 1977-2016 yılları arasındaki toplam ihracat-ithalat verileri ticaret hacmi olarak ve bu yıllar arasında demiryolu taşımacılı̆ıyla taşınan yük miktarı ise tonaj olarak ele alınarak korelasyon ve regresyon analizleri yapılmıştır. Bu analizlerin sonucunda iki değişken arasında pozitif yönlü doğrusal bir ilişki tespit edilmiş ve ticaret hacmindeki \%1'lik artışın tonajda \%0,35'lik bir artışa neden olduğu saptanmıştır. Bu verilere göre Türkiye'nin 2023 yılında hedeflediği 1,17 trilyon dolarlık ticaret hacmine ulaşabilmesi için ticaret hacminin \%243 oranında artması gerektiği göz önünde bulundurulduğunda, demiryoluyla taşınan tonaj miktarının \%85 artacağı hesaplanmıştır. Bu sonuca göre demiryollarının ciddi yatırımlara ihtiyacı olduğu sonucuna varılmıştır.

Ancak bu noktada, demiryollarının ne kadar verimli kullanıldı̆̆ı sorusu gündeme gelmektedir. Çünkü mevcut altyapının verimsiz kullanılması büyük maliyetli yatırımlardan çok etkinliği arttırıcı küçük yatırımlar ve düzenlemelerle daha iyi sonuçlar alabilmeyi sağlayacaktır. Bu noktada altyapının etkinliğinin hesaplanması büyük önem arz etmektedir. Bu noktada altyapı ve tedarik zinciri yönetimi konusunda bizden daha iyi seviyelerde olan Avrupa Birliği ülkeleriyle bir kıyaslama uygun görülmüştür. Ancak Türkiye ile etkinlikleri kıyaslanacak olan ülkelerin Türkiye ile bezer özelliklere sahip olması sağlıklı sonuçlar almak açısından önem arz etmiştir. Çünkü etkinlik ölçü yöntemi olan VZA minimum girdiyle maksimum çıktıyı elde etmeyi hedef aldığı için, göreceli olarak küçük ve transit yüklerin yoğun olduğu ülkeler en verimli çıkacak ve sonuçlarda büyük sapmalara neden olacaktır. Bu noktada hiyerarşik kümeleme analizi ile ülkeler GSYiH, ürün ithalatı, ürün ihracatı, nüfus ve yüz ölçümü özelliklerine göre kümelendirilmişlerdir. Türkiye bu analiz sonucunda, Birleşik Krallık, İtalya ve Fransa ile beraber bir küme oluşturulmuşlardır.

Kıyaslama yapılacak ülke grubu belirlendikten sonra ise bu 4 ülke, demiryolu ağlarının uzunluğu girdi ve taşınan yük miktarı ton-km birimi cinsinden çıktı olarak modele dâhil edilerek etkinlikleri ölçülmüştür. Çünkü ton-km en yaygın kullanılan performans göstergelerinden biri olarak öne çıkmaktadır. Model çıktı odaklı olarak kullanılmış ve sonuçlara göre en etkin ülke Birleşik Krallık olurken, etkinliği en düşük ülke 0,74 skoruyla Türkiye olmuştur. Çıktı odaklı modelin sunduğu projeksiyona göre ise 2016 yılında gerçekleştirilen 10,178 milyar ton-km tutarındaki taşıma işleminin, en etkin ülke temel alındığında mevcut altyapıyla 13,744 milyar ton-km olarak gerçekleştirilebilmesi mümkündür. Bir diğer deyişle ülke altyapısı \%74 oranında etkin kullanılmaktadır. Buradan etkinliği arttııcı yatırımlarla mevcut altyapının daha yüksek taşıma hacimlerine hizmet edebileceğini göstermektedir.

Etkinliği arttırıcı kısa vadeli öneriler şu şekilde sıralanabilirler; çoklu taşıma modlarının yaygınlaştırılması için yasal zeminin düzenlenmesi, demiryolu taşımacılığındaki rekabetin arttırılması ve girişimcilerin ilgisinin çekilmesi, özel sektörün ilgisinin arttırılmasıyla teknoloji izlemenin kolaylaştırılması ve demiryolu taşımacılı̆̆ı kullanan firmalara teşviklerin sağlanması. Uzun 
vadede öneriler ise şu şekilde sıralanabilirler; demiryolu ağının kapsamının genişletilmesi, limanlara bağlantıların güçlendirilmesi, aktarma merkezlerinin sayısının artııııması, Ulaştırma Ana Planı kapsamından demiryolu yatırım önceliklerinin belirlenmesi, yerli teknolojilerin teşvik edilerek yatırım, işletme ve bakım maliyetlerinin sürdürülebilir seviyede tutulması, lojistik üslerinin sanayilerin yakınlarında olacak şekilde kurulması ve teşvik edilmesi.

İleriki çalışmalar için bazı öneriler şunlardır; panel veri analizi kullanılarak, demiryolu taşımacılığıyla ticaret hacmi arasındaki ilişki birden çok ülke temel alınarak tespit edilebilir; kümeleme analizinde kullanılan değişkenler literatür baz alınarak yeniden tespit edilerek analiz daha sağlıklı hale getirilebilir; veri zarflama analizinde kullanılan girdi ve çıktı değişkenlerinin sayıları arttırılabilir; ekonomik aktivitelerin diğer taşıma modlarıyla olan ilişkisi de araştırılabilir; ve son olarak sektör paydaşlarıyla görüşmeler yapılıp etkinsizliğin nedenleri ve çözüm yolları nitel olarak analiz edilebilir.

\section{REFERENCES}

Altınok, S. (2001). Türkiye'de ulaştırma politikaları, karayolları ve demiryollarının mukayesesi. SÜ iiBF Sosyal ve Ekonomik Araştırmalar Dergisi, 1(2), 73-87.

Anderson, F. N. G., Elger, T. (2012). Swedish freight demand: short, medium, and long- term elasticities. Journal of Transport Economics and Policy, 46(1), 79-97.

Banker, R. D., Charnes, A., Cooper, W. W. (1984). Some models for estimating technical and scale inefficiencies in data envelopment analysis. Management Science, 30(9), 1078-1092.

Gargett, D., Aroia, L. (1990). Freight flows in Australian transport corridors. Occasional paper. Publication of: Australian Government Publishing Service, (98).

Chang, M. (2014). Principles of scientific methods. CRC Press.

Charnes, A., Cooper, W. W., Rhodes, E. (1978). Measuring the efficiency of decision making units. European Journal of Operational Research, 2(6), 429-444.

Cook, W. D., Tone, K., Zhu, J. (2014). Data envelopment analysis: prior to choosing a model. Omega, 44, 1-4.

Çekerol, G., Nalçakan, M. (2011). Lojistik sektörü içerisinde türkiye demiryolu yurtiçi yük taşıma talebinin ridge regresyonla analizi. Marmara Üniversitesi i.i..B.F. Dergisi, 31(2), 321-344.

Eurostat (2017). Milyar ton-km ve toplam demiryolu uzunluğu. https://ec.europa.eu/transport/facts-fundings/statistics/pocketbook2017_en.

İnan, M., Demir, M. (2017). Demiryolu ulaşımı ve Türkiye'de hızlı tren yatırımlarının etkileri: Eskişehir-Konya örneği. Fırat Üniversitesi Sosyal Bilimler Dergisi, 27(1), 99-120.

Kabasakal, A., Solak, A. O. (2008). Evrensel hizmet yükümlülüğünün uygulanması ve Türk demiryolu sektörü. Bilgi Ekonomisi ve Yönetimi Dergisi, 3(2), 137-146

Kabasakal, A., Solak, A. O. (2009). Demiryolu sektörünün rekabete açılması. Dumlupınar Üniversitesi Sosyal Bilimler Dergisi, 25, 27-34.

Karagöz, Y. (2016). SPSS ve AMOS 23 uygulamalı istatiksel analizler. Nobel Akademik, Ankara.

Kasapoğlu, L., Cerit, A. G. (2011). Türkiye'de intermodal konteyner taşımacılığında demiryolu ulaştırma potansiyelinin analizi. Dokuz Eylül Üniversitesi Denizcilik Fakültesi Dergisi, 3(1), 59-72.

Kaynak, M. (2002). Yeni demiryolu çağı yüksek hızlı trenler ve Türkiye. Ekonomik Yaklaşım, 13, (42-43), 23-53.

Productivity Commission (2006). Road and rail freight infrastructure pricing. Inquiry Report 41. Productivity Commission, Melbourne, VIC.

Rao, P. S. (1978). Forecasting the demand for railway freight services. Journal of Transport Economics and Policy, 12, 7-26.

Saatçioğlu, C., Çankırı Kolbaşı, N. (2012). Türkiye lojistik sektöründe denizyolu-demiryolu entegrasyon sürecinin incelenmesi, Sakarya İktisat Dergisi, 1(2), 1-25

Song, M., Zhang, G., Zeng, W., Liu, J., Fang, K. (2016). Railway transportation and environmental efficiency in China. Transportation Research Part D: Transport and Environment, 48, 488-498.

Tuna, O. (2011). Türkiye için lojistik ve denizcilik stratejileri: uluslararası ve bölgesel belirleyiciler. Dokuz Eylül Üniversitesi Sosyal Bilimler Enstitüsü Dergisi, 3 (2).

TÜiK (2017). Demiryoluyla taşınan yük. http://www.tuik.gov.tr/PrelstatistikTablo.do?istab_id=1584 yük.

World Bank (2017a). Toplam ihracat. https://data.worldbank.org/indicator/TX.VAL.MRCH.CD.WT.

World Bank (2017b). Toplam ithalat. https://data.worldbank.org/indicator/TM.VAL.MRCH.CD.WT. 
World Bank (2017c). GSYiH. https://data.worldbank.org/indicator/NY.GDP.MKTP.CD.

World Bank (2017d). Ürün ihracatı. https://data.worldbank.org/indicator/NE.EXP.GNFS.CD.

World Bank (2017e). Ürün ithalatı. https://data.worldbank.org/indicator/NE.IMP.GNFS.CD.

World Bank (2017f). Nüfus. https://data.worldbank.org/indicator/SP.POP.TOTL.

World Bank (2017g). Ülke alanı. https://data.worldbank.org/indicator/AG.LND.TOTL.K2.

Woroniuk, C., Marinov, M., Zunder, T., Mortimer, P. (2013). Time series analysis of rail freight services by the private sector in Europe. Transport Policy, 25, 81-93. 